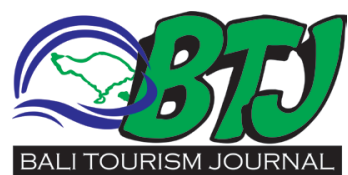

\title{
War against plastic, a genuine commitment of Denpasar City in prevailing Tri Hita Karana concept
}

\author{
Ida Bagus Komang Surya Werdiyasa ${ }^{1}$
}

\section{ABSTRACT}

On the first day of 2019, Government of Denpasar City, Bali, published a new regulation, namely Mayor Regulation No. 36/2018 (Perwali No. 36 Tahun 2018) to minimize the usage of plastic, as single used shopping Bags in Denpasar City. The regulation has been active since January 1,2019. Plastic has become part of modern days civilization. Various industries apply the usage of plastic, due to its durability, lightweight and easy to afford. However, beyond all the convenience it offers, turns out a terrible fact awaits; a hazardous plastic waste that impossible to decompose naturally. Plastic is classified into seven types according to its composition, they are Polyethylene Terephthalate (PET), High-Density Polyethylene (HDPE), Polyvinyl Chloride (PVC), Low-Density Polyethylene (LDPE), Polypropylene (PP), Polystyrene (PS) and the '0.' Plastic is recyclable, nevertheless, it mostly ended in the ocean, due to the finite availability of plastic recycler in Indonesia, as well as low social awareness in keeping the environment clean. Mayor Regulation No.36/2018 is an effort of Denpasar city to minimize single-use plastic bag. The Government through the local regulation suggests shopping centers and modern stores provide environmentalfriendly alternative bags with biodegradable standard or permanent bags that can be used repeatedly, to reduce society's dependence on using single-use plastic bags when shopping. The regulation is a clear example of Denpasar City in preserving the environment based on the philosophical foundation of the concept of Tri Hita Karana. It is a Balinese concept to maintain harmonious relationships between humans to God, among humankind, as well as human and their environment.
${ }^{1}$ Mediterranean Bali, Hotel \& Cruise Line Training Centre gusmang848@gmail.com

\section{Editor:}

Ida Bagus Ngurah Tri Pramana

Received: 2019-02-06 Accepted: 2019-02-20 Published: 2019-04-5

Keyword: Mayor Regulation, Plastic bag, Tri Hita Karana

Cite This Article: Werdiyasa, I.B.K.S., War against plastic, a genuine commitment of Denpasar City in prevailing Tri Hita Karana concept Bali Mandara Nawanatya. Bali Tourism Journal (BTJ)2019, 3 (1): 1-4

\section{INTRODUCTION}

On the first day of 2019, Government of Denpasar City, Bali, published a new regulation, namely Mayor Regulation No. 36/2018 (Perwali No. 36 Tahun 2018). The regulation instructs to minimize the usage of plastic as single used shopping Bags in Denpasar City and has been active since January 1, 2019. The government of Denpasar creates regulation as an attitude towards the worrying number of plastic wastes in the city. Plastic has become part of modern days civilization. Various industries apply the usage of plastic, due to its durability, lightweight and easy to afford. However, beyond all the convenience it offers, turns out a terrible fact awaits; a hazardous plastic waste that impossible to decompose naturally. As a result, it has been piling up, while constant exposure to sunlight make it break into micro-size and polluting the environment, both land and water. Its existence disrupts the balance of natural ecosystems, as well as gives a significant impact on the continuity of the food chain that sustains life on earth. ${ }^{1-4}$

Since 2014, The usage of plastic in Industry has been reported significantly increased every year. Various types of plastics being produced throughout the world with a total production exceeding 300 million per year. ${ }^{5}$ Indonesia treats the act to control plastic waste as a top priority, due to recent data from the Indonesian Plastic Industry Association (Inaplas) and the Central Statistics Agency (BPS), mentioned that Indonesia ranks number two as a contributor of plastic waste in the world after China. ${ }^{6}$ It is necessary to raise social awareness regarding this pollution effect on the planet earth. Thus, the number of plastic wastes may be reduced to zero in the future.

This writing aims to provide brief information about Mayor Regulation No. 36/2018, as well as to raise the social awareness by giving explanations regarding types of plastic, its usage in industry and the impact caused by its waste.

\section{PLASTIC RESIN AND ITS CLASSIFICATION}

Industry in these modern days, widely uses seven types of plastic, namely Polyethylene Terephthalate, High-Density Polyethylene, Polyvinyl Chloride, LowDensity Polyethylene, Polypropylene, Polystyrene and 'O.' it is classified based on its composition, with a label number written on the product. The first type 

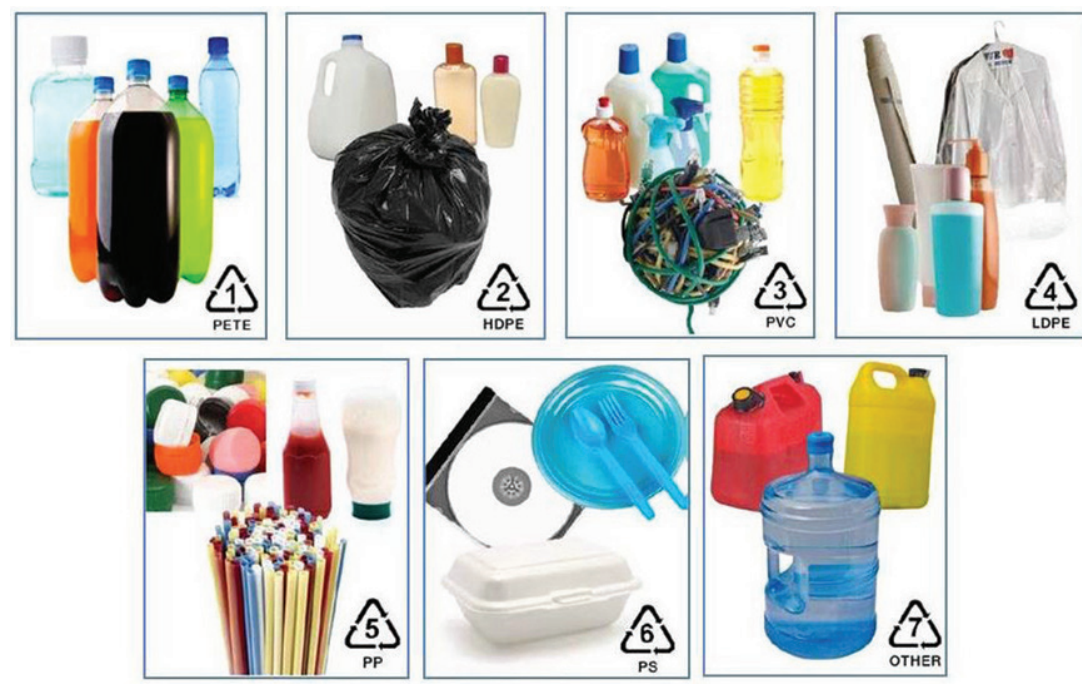

Figure 2. Plastic resin and its classification ${ }^{8}$

is Polyethylene Terephthalate (PET), with code number 1 . the primary material to make single used mineral water bottles or mineral water cup. It has a transparent color, and if exposed to high temperature, will release carcinogenic substances. PETE or PET can be recycled into household furniture, carpets, and life jackets.

The second type is High-Density Polyethylene (HDPE), with code number 2. In industry, this milky white colored plastic becomes basic material for shampoo or detergent container. It is heatresistant, however the longer it is used, the plastic will release harmful substance namely Antimony Trioxide. HDPE plastic can also be processed into ropes, toys, and pipes.

The third type is Polyvinyl Chloride (PVC or $\mathrm{V})$ with code number 3. It is difficult to recycle, and commonly processed as the primary material for pipes, window frames, non-food bottles, toys, plastic chairs, and automotive components.

Next, it is Low-Density Polyethylene (LDPE) with code number 4 . This type of plastic does not cause any chemical reactions if it exposes to other objects including food and drink, however, it is difficult to decompose. Plastic bags, food containers, and bottle dispensers are mainly composed of this type of plastic. LDPE can be recycled into household furniture and trash cans.

Furthermore, there is Polypropylene (PP) with code number 5, used for bottle caps, food containers (plates, bowls, lunch boxes), medicine bottles and baby drink bottles. This type of plastic is heat resistant, transparent and has slightly shiny color.

Polystyrene (PS) is commonly known as

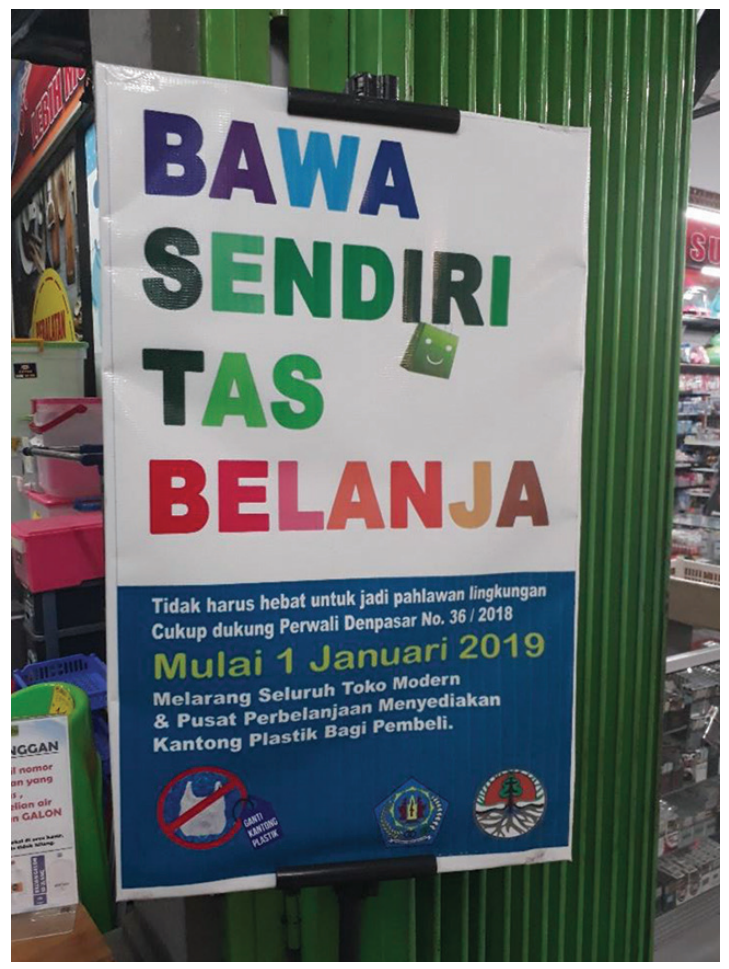

Figure 1. A poster depicted Mayor Regulation No. 36/2018 (Perwali No. 36 Tahun 2018). The regulation instructs the society to minimize the usage of Plastic as single used shopping Bags in Denpasar City, and has been active since January 1, $2019 .^{7}$

Styrofoam. This type of plastic in some countries, used as a single used container for food and beverage. A recent study discovered that PS plastic is detrimental to health since it contains styrene, a substance that can cause brain and nerve disorders, brain as well as harmful to female reproduction. Therefore, many countries have decided to ban the use of plastic number 6 for food.

Last but not least, the 'O.' it stands for Other: SAN (Styrene Acrylonitrile), ABS (Acrylonitrile Butadiene Styrene), PC (Polycarbonate), and Nylon. This type of plastics composed of mixtures of 2 or more types of plastic. It is extremely dangerous if in contact with food. The plastic is used for household appliances, electronic equipment, packaging, and automotive parts. ${ }^{9}$

Although most types of plastic are considered recyclable, however, the availability of technology to recycle plastic in Indonesia is considerably limited. The littering habit as well as unsuccessful recycle resulting plastic waste mixed with other types of waste, piling up, washed away in the river and ended up in the ocean.

The pollution of plastic in the ocean becomes 


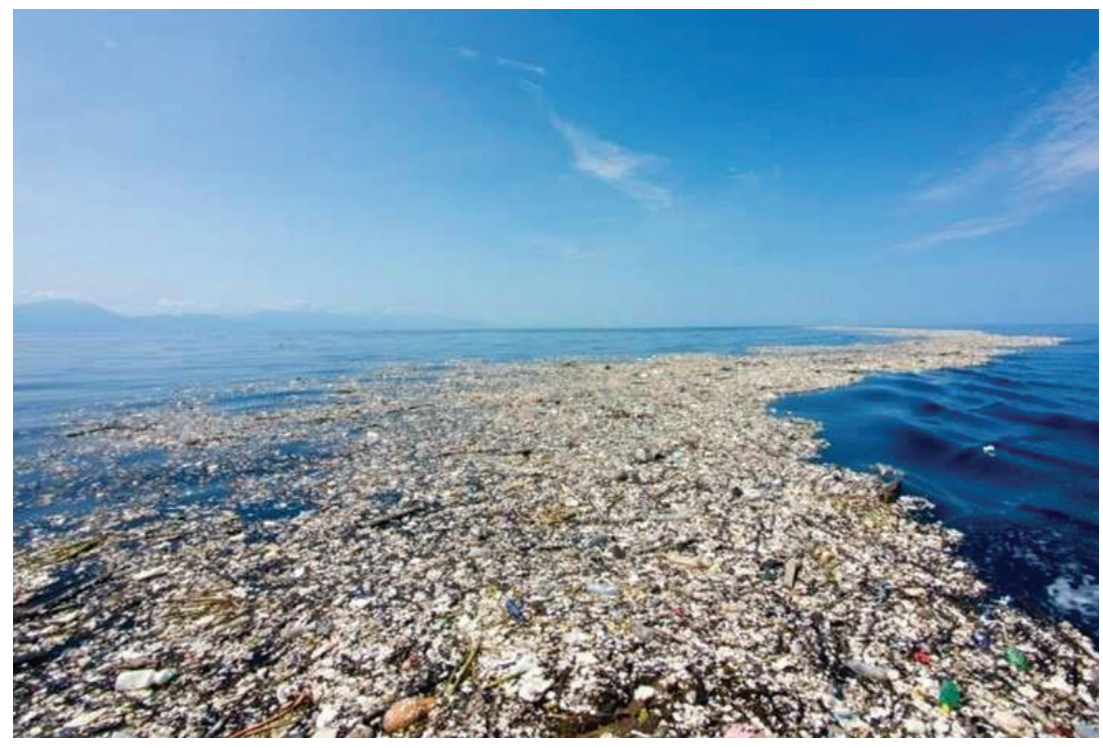

Figure 3. The Garbage Patch ${ }^{10}$

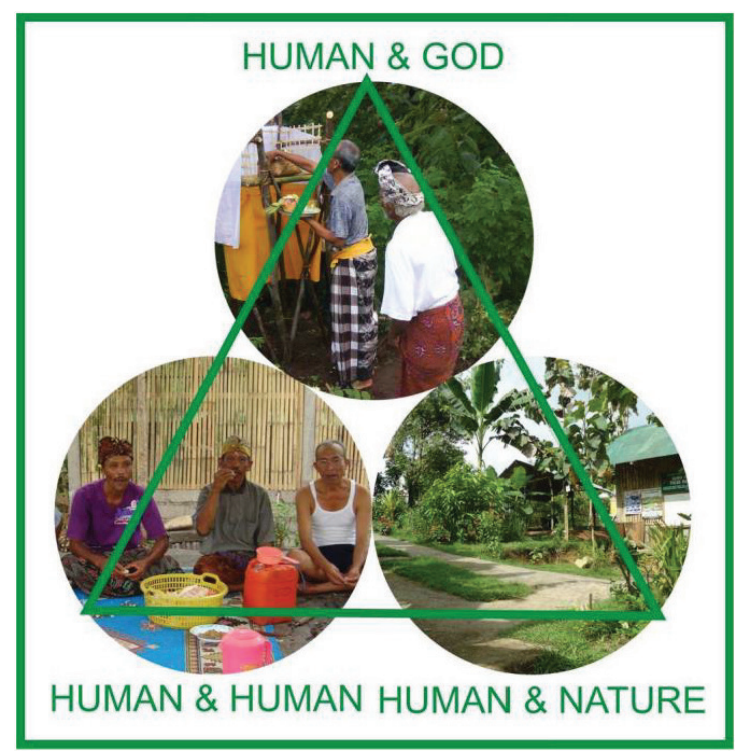

Figure 4. Illustration of Tri Hita Karana concept

permanent bags that can be used repeatedly, to reduce people's dependence on using single-use plastic bags when shopping.

The United States and Europe experienced a significant reduction in the amount of plastic waste, after applying a 'plastic diet.' According to the information presented in the Bali Post media, as cited from ReuseThisBag.com, it is revealed that in the City of San Jose, California, there was a 59 percent decline in plastic waste in residential areas and a 60 percent decrease in plastic waste in rivers since the year 2012. Meanwhile, in the City of Seattle, within five years plastic waste in housing fell by 48 percent. A similar finding in European region, Ecowatch reported that the Center for Environment, Fisheries and Aquaculture Science (CEFAS) noted a dramatical decrease in the amount of plastic waste, around 30 percent in Norwegian, German, French and Irish waters.

Although it has been implementing in early 2019, Head of the Denpasar City Environment and Hygiene Agency, Ketut Wisada, explained that the regulation had been introduced since July 2018 to the public. The officer informed shop, traditional markets, to grocery stores to provide alternative bag due to future regulation. Prevailing the regulation is a real commitment of the government in preserving the environment based on the philosophical foundation of the concept of Tri Hita Karana. Tri Hita Karana is a concept of Balinese society to maintain harmonious relationships between humans to God, among humankind, as well as human and their environment. ${ }^{13}$

Supervision, outreach, and monitoring of the regulation enforcement continue to be carried out; 
thus, Denpasar City may be free from plastic waste. Information dissemination and supervision are carried out to ensure compliance of business entity and consumers in reducing plastic waste. From the results of monitoring, most shops, supermarkets, and stalls have complied Regulation Number 36 of 2018. nevertheless, only few shops to be found have not obey the regulation. ${ }^{14}$

\section{CONCLUSION}

Plastic is classified into seven types according to its composition, they are Polyethylene Terephthalate (PET), High-Density Polyethylene (HDPE), Polyvinyl Chloride (PVC), Low-Density Polyethylene (LDPE), Polypropylene (PP), Polystyrene (PS) and 'O'. Plastic is recyclable. However, it mostly ended in the ocean due to the finite availability of plastic recycler in Indonesia, as well as low social awareness in keeping the environment clean. Mayor Regulation No.36/2018 is an effort of Denpasar city to minimize singleuse plastic bag. The Government through the local regulation suggests shopping centers and modern stores provide environmental-friendly alternative bags with biodegradable standard or permanent bags that can be used repeatedly, to reduce society's dependence on using single-use plastic bags when shopping. The regulation is a clear example of Denpasar City in preserving the environment based on the philosophical foundation of the concept of Tri Hita Karana. It is a Balinese concept to maintain harmonious relationships between humans to God, among humankind, as well as human and their environment.

\section{REFERENCE}

1. Wilcox C, Van Sebille E, Hardesty BD. Threat of plastic pollution to seabirds is global, pervasive, and increasing. Proceedings of the National Academy of Sciences. 2015 Sep 22;112(38):11899-904.

2. G Prayitno. Masalah Sampah Plastik di Bali: Rusak Pariwisata dan Ancam Ikan Mola-mola di Perairan Nusa Penida. Tribuntravel. 2019. Available at URL: http://travel. tribunnews.com/2019/02/23/masalah-sampah-plastik- di-bali-rusak-pariwisata-dan-ancam-ikan-mola-mola-diperairan-nusa-penida?page $=$ all .

3. Anonymous. Paus Mati di Filipina, Perutnya Berisikan 40 Kg Plastik. VOA Indonesia. 2019. Available at URL: https:// www.voaindonesia.com/a/paus-mati-di-filipina-perutnyaberisikan-40-kg-plastik/4836596.html

4. Anonymous. Paus di Wakatobi telan ' 115 gelas plastik' dan sandal jepit. BBC. 2018. Available at URL: https://www.bbc. com/indonesia/indonesia-46284830

5. Lebreton LC, Van der Zwet J, Damsteeg JW, Slat B, Andrady A, Reisser J. River plastic emissions to the world's oceans. Nature communications. 2017 Jun 7;8:15611.

6. M L Kesuma. Menuju Bali bebas Sampah Plastik. Bali Post. 2019. Available at URL: http://www.balipost.com/ news/2019/01/28/67311/Menuju-Bali-Bebas-SampahPlastik.html

7. Image by IBNT Pramana. 2019. Private collection.

8. Image taken from Ciri-ciri Wadah Makanan Plastik yang Aman Bagi Kesehatan. njajan[dot]com. 2018. Available at URL: https://www.njajan.com/2018/06/ciri-ciri-wadahmakanan-plastik-yang-aman.html

9. P Firscha. Ketahui 7 Macam Jenis Plastik dan Bahaya Mengancamnya Bagi Kesehatanmu. Idntimes. 2018. Available at URL: https://www.idntimes.com/science/ discovery/patricia-firscha/7-macam-jenis-plastik-danrisiko-kesehatannya/full.

10. Image taken from P Galey, M Hood. Pacific plastic dump far larger than feared: study. phys[dot]org. 2018. Available at URL: https://phys.org/news/2018-03-pacific-plasticdump-larger.html

11. N Akpan. Great Pacific Garbage Patch weighs more than 43,000 cars and is much larger than we thought. $\mathrm{Pbs}$ [dot]org. 2018. Available at URL: https://www.pbs.org/newshour/ science/the-great-pacific-garbage-patch-weighs-morethan-43000-cars-and-is-way-bigger-than-previouslythought.

12. Image by $\mathrm{K}$ Budi. Keseimbangan Tri Hita Karana. Kramabali[dot]com. 2017. Available at URL: http:// kramabali.com/keseimbangan-tri-hita-karana/

13. BALI RT. Peraturan Daerah Provinsi Bali Nomor 16 Tahun 2009. Tentang Rencana Tata Ruang Wilayah Provinsi Bali Tahun. 2009;2029.

14. Asmara. Penerapan Perwali 36/2018, Sidak Toko Modern. Bali Post. 2019. Available at URL: http://www.balipost. com/news/2019/01/02/65067/Penerapan-Perwali-362018,Sidak-Toko...html

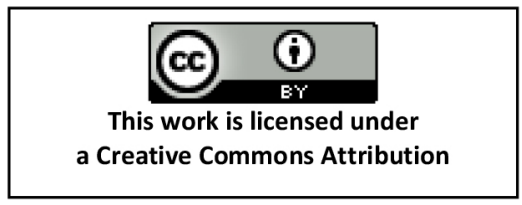

